MATEC Web of Conferences 25, 04006 (2015)

DOI: $10.1051 /$ matecconf/ 20152504006

(C) Owned by the authors, published by EDP Sciences, 2015

\title{
Analysis about the Influence of Clay Core Wall Structure towards the Slope Stability of High Embankment Dam
}

\author{
Bin Li \& Zhijun Chen \\ Tianjin Port Engineering Institute Ltd. of CCCC First Harbor Engineering Company Ltd., Tianjin, China \\ Key laboratory of port geotechnical engineering, ministry of communications, PRC Tianjin, China \\ Key laboratory of port geotechnical engineering of Tianjin, Tianjin, China
}

\begin{abstract}
As the main part of the anti-seepage system, core wall is a key point in the design of high embankment dam. The dam slope stability is a major factor for the type of core wall. But it is still unclear what effects the core wall structure might have on the slope stability. Based on practical projects of high embankment dam in Nuozhadu, Lianghekou and Shuangjiangkou, this paper analyzes safety factors and dangerous slip surfaces of dam slopes of high embankment dams in both straight and slanting core wall structures and compares the influences of different core wall structures on the slope stability of high embankment dam through numerical calculations. The safety margin of the embankment dam of straight core wall is larger than that of slanting core wall in the operating condition of the reservoir water level's drawdown. Compared with that of the straight core wall scheme, the position of the dangerous slip surface of the downstream dam slope is closer to the dam crest in the slanting core wall scheme.
\end{abstract}

Keywords: high embankment dam; core wall type; dam slope stability; safety factor ${ }^{1}$

\section{INTRODUCTION}

With the domestic popularization and application of heavy earth-moving machineries and corollary equipment, the construction of embankment dam in China has been rapidly developed. For the past few years, the construction of ultrahigh embankment dams built on the thick overburden layer like Nuozhadu, Lianghekou and Shuangiiangkou has provided strong support for the development of the $300 \mathrm{~m}$ ultrahigh core wall dam construction technique in China ${ }^{[1-3]}$. It is appropriate to use local materials to build high dams on overburden layers of meizoseismal areas in consideration of the perfect adaptability and anti-seismic property of the embankment dam. Clay core wall, concrete face and asphalt concrete core wall can be applied in the anti-seepage of dam.

The concrete face rock-fill dam is a new type rock-fill dam which is rapidly developed in recent years. This dam type has such great advantages as convenient construction, weather protected, short construction period and low project cost. It has been widely used in our country in recent years. The maximum dam height of the first class concrete embankment dam built domestically reaches $178 \mathrm{~m}$ and the Shuibuya project dam is as high as more than $233 \mathrm{~m}$. However, most concrete embankment dams at home and abroad are built on bed rocks (toe boards are placed on batholiths) and the concrete embankment dams built on the overburden layer are projects with low dams (the maximum dam height is about $100 \mathrm{~m}$ and the overburden layer thickness is less than $50 \mathrm{~m}$ ). There are problems existing in the construction of concrete embankment dam on thick overburden layer, such as complicated anti-seepage structure, poor anti-seepage reliability, sealing on the joint of the basic anti-seepage wall and the connecting plate as well as that on the joint of the connecting plate and the concrete face might be easily destroyed due to uneven deformations, and the anti-seepage property of the concrete face might be influenced by tension cracks caused by excessive deformations and so on. For the $250 \mathrm{~m}$ high dam on the thick overburden layer of the meizoseismal area, the concrete face is adopted for anti-seepage. Technical difficulties are extremely huge no matter the overburden layer is entirely excavated out or the dam is built on the overburden layer.

Rock-fill dams with asphalt concrete core wall are generally built on batholiths. Main technical problems of building it on thick overburden layer are similar to those of concrete embankment dam. At present, experience in building ultrahigh rock-fill dams with asphalt concrete core wall at home and abroad is not yet mature. As for the Yele hydropower station project of Nanyahe, the maximum height of the rock-fill dam with asphalt concrete core wall is $125.50 \mathrm{~m}$ and the thickness of the dam foundation overburden reaches more than $100 \mathrm{~m}$. But in Yele project, the overburden layer is mainly over-consolidated soil, the mass of which has different levels of calcite cementation and the mechanical strength index of which is much larger than those of general riverbed overburden layers. So the sedimentation deformation of Yele dam foundation is relatively small. The $250 \mathrm{~m}$ high dam on the thick overburden layer of the meizoseismal area is constructed with the rock-fill dam with asphalt concrete 


\section{MATEC Web of Conferences}

core wall, of which stress and deformation of the dam foundation concrete anti-seepage wall and the core wall are extremely complicated with huge technical difficulties. Therefore, the rock-fill dam with asphalt concrete core wall will not be taken into account.

Rock-fill dam with a clay core wall is the type of dam frequently adopted by water conservancy and hydropower projects at home and abroad. The Nurek embankment dam with a clay core wall of the former Soviet Union is as high as $300 \mathrm{~m}$. Heights of rock-fill dams with a clay core wall which is built domestically, including Pubugou, Xiaolangdi, Bikou and Lubuge, are more than $100 \mathrm{~m}$. Built on the overburden layer of $70 \mathrm{~m}$, the dam of Pubugou project is as high as $186 \mathrm{~m}$. All these projects can be used as a reference of this project. According to incomplete statistics, there are 11 embankment dams with a height of more than $230 \mathrm{~m}$, including those have been built and those under construction. All these dams are anti-seepage type with clay core walls, four of which are constructed with straight core walls and seven are constructed with slanting core walls.

In consideration of such facts as mature design and construction experience of constructing high rock-fill dams with clay core wall on thick overburden layer, rich reserves of easily mined and qualified gravel soil and rock-fill material at the dam site, proper weather conditions for the filling of anti-seepage soil material (core wall), the dam height of the project, the thickness of dam foundation overburden and the high seismic intensity of the dam site, the rock-fill dam with gravel soil core wall is adopted for the construction of the dam. Types of core walls of clay rock-fill dam include straight core wall, slanting core wall, arc core wall and so on. As for high clay core wall rock-fill dams on thick overburden layer, anti-seepage wall is generally adopted by the dam foundation overburden. At present, arc anti-seepage wall is rarely used domestically in light of the convenience of connecting the anti-seepage wall and the clay core wall. Both straight core wall and slanting core wall have their own advantages and disadvantages. Two kinds of core wall dams of the constructed high rock-fill dam with a clay core wall have successful cases. So a comparative study is carried out on the two types of core walls. The idea of the comparison: Taking the Changhe Dam for example, the dam structure can be designed divisionally according to different structural features of two core wall rock-fill dams. Choose typical dam cross sections and analyze advantages and disadvantages of two core wall types through calculations on two-dimensional seepage, dam slope stability and plane stress and strain. Select appropriate clay core wall types through comprehensive comparisons of dam structure, direct investment, construction period and other aspects.

According to the construction experience of $200 \mathrm{~m}$ high embankment dam ${ }^{[4-5]}$, it can be known that the safe operation of a dam mainly depends on the skid resistance stability of dam slope, the seepage stability of dam materials and the stability of dam deformation. The stability of the embankment dam slope and body in design and operation is an especially crucial factor. Therefore, it is very necessary to analyze the influence of core wall type selection on dam slope stability and dam stress, especially for high embankment dams of more than $200 \mathrm{~m}$ without a complete set of design criteria and a safety evaluation system ${ }^{[6-8]}$. Based on three ultrahigh core wall dam projects in Nuozhadu, Lianghekou and Shuangjiangkou, this paper compares slope stabilities of different core wall structures ${ }^{[9-11]}$ and provides a reference for the core wall selection of high embankment dams of this kind.

\section{GENERAL SITUATIONS OF PROJECTS}

\section{1) Nuozhadu project}

Nuozhadu Hydropower Station is located in the junction of Simao district of Puer City and Lancang County in the lower reaches of the Lancang River. It is not only a core project of the downstream hydropower of the Lancang River but also a major power source for the delivery of electricity in Yunnan. The hydropower station hub is composed of a core wall rock-fill dam, a left bank spillway, a left diversion and a power generation system. The dam body of Nuozhadu reservoir is a straight core wall of gravel soil, the maximum dam height and the dam crest width of which are respectively $261.5 \mathrm{~m}$ and $18 \mathrm{~m}$. Both sides of the core wall are reversed filters, the outside of which is the dam shell of rock-fill material.

2) Lianghekou project

Lianghekou Hydropower Station is located in the lower reaches of the confluence of the Yalong mainstream and the tributary Qindahe in Yajiang County, Ganzi State of Sichuan Province. It is the "leading" reservoir in the middle and lower reaches of the Yalong River. The hub is composed of a clay core wall rock-fill dam, a tunnel spillway, a flood discharging tunnel, an emptying tunnel, an underground power house and water diversion and tailrace structures. The maximum dam height and the dam crest width of the clay core wall rock-fill dam are respectively $295 \mathrm{~m}$ and $16 \mathrm{~m}$. The upstream slope ratio and the downstream slope ratio are respectively $1: 2$ and 1:1.9. Both sides of the core wall are reversed filters and a transition layer is installed between the reversed filter and the dam shell of rock-fill material.

3) Shuangjiangkou project

Shuangjiangkou Hydropower Station is the fifth grade power station of the "three reservoirs and 22 grades" of the tributary of the Dadu River. It is a controlling reservoir project in the upper reaches of the Dadu River. The pivotal project is composed of a barrage, release structures and a water diversion and power generation system. The maximum dam height and the dam crest width of the clay core wall rock-fill dam are respectively $314 \mathrm{~m}$ and $16.00 \mathrm{~m}$. Two layers of reversed filters are installed on both sides of the core wall and a transition layer is installed between the upstream and downstream reversed filter II and the rock-fill material of the dam body. 
EMME 2015

Table 1. Structural design parameters of high embankment dam

\begin{tabular}{lllllllll}
\hline Dam & $\begin{array}{l}\text { Dam } \\
\text { height } \\
\mathrm{m}\end{array}$ & $\begin{array}{l}\text { Core wall } \\
\text { material }\end{array}$ & $\begin{array}{l}\text { Upstream } \\
\text { dam } \\
\text { slope }\end{array}$ & $\begin{array}{l}\text { Downstream } \\
\text { dam slope }\end{array}$ & $\begin{array}{l}\text { Width of } \\
\text { core wall } \\
\text { crown }\end{array}$ & $\begin{array}{l}\text { Slope of } \\
\text { core } \\
\text { wall }\end{array}$ & $\begin{array}{l}\text { Slope } \\
\text { reversed } \\
\text { filter }\end{array}$ & $\begin{array}{l}\text { Thickness } \\
\text { of reversed } \\
\text { filter }\end{array}$ \\
\hline Nuozhadu & 261.5 & $\begin{array}{l}\text { Gravel } \\
\text { soil }\end{array}$ & $1: 1.9$ & $1: 1.8$ & $10 \mathrm{~m}$ & $1: 0.2$ & $1: 0.2$ & $4 \mathrm{~m} / 6 \mathrm{~m}$ \\
Shuangjiangkou & 314 & $\begin{array}{l}\text { Gravel } \\
\text { soil } \\
\text { Gravel }\end{array}$ & $1: 2.0$ & $1: 1.9$ & $4 \mathrm{~m}$ & $1: 0.2$ & $1: 0.2$ & $4 \mathrm{~m} / 6 \mathrm{~m}$ \\
Lianghekou & 295 & $\begin{array}{l}1: 2.0 \\
\text { soil }\end{array}$ & $1: 1.9$ & $6 \mathrm{~m}$ & $1: 0.2$ & $1: 0.2$ & $4 \mathrm{~m} / 6 \mathrm{~m}$ \\
\hline
\end{tabular}

Table 2. Parameters of the stability calculation of Nuozhadu dam

\begin{tabular}{lcccccccc}
\multicolumn{1}{l}{ Table 2. Parameters of the stability calculation of Nuozhadu dam } \\
\hline & \multicolumn{3}{c}{ Linear strength } & \multicolumn{3}{c}{ Nonlinear strength } \\
Dam materials & $\mu_{f}$ & $\sigma_{f}$ & $\mu_{c}$ & $\sigma_{c}$ & $\mu_{\phi}$ & $\sigma_{\phi}$ & $\mu_{\Delta \phi}$ & $\sigma_{\Delta \phi}$ \\
\hline (1) Rock-fill material of division I & & & & & 53.669 & 2.576 & 7.748 & 0.775 \\
(2) Rock-fill material of division II & & & & & 51.213 & 2.509 & 8.421 & 0.842 \\
(3) Mixed soil material & 0.351 & 0.035 & 180.421 & 39.693 & & & & \\
(4) Soil material mixed with gravel & 0.421 & 0.042 & 239.205 & 47.841 & & & \\
(5) Fine rock-fill material & & & & & 51.213 & 2.509 & 6.207 & 0.621 \\
(6) Reversed filter material & & & & & 52.047 & 2.550 & 9.316 & 0.932 \\
\hline
\end{tabular}

Table 3. Parameters of the stability calculation of Shuangjiangkou dam

\begin{tabular}{|c|c|c|c|c|c|c|}
\hline \multirow[b]{2}{*}{ Materials } & \multicolumn{3}{|l|}{$\phi_{0}\left(^{\circ}\right)$} & \multicolumn{3}{|l|}{$\Delta \phi\left(^{\circ}\right)$} \\
\hline & Average & $\begin{array}{l}\text { Standard } \\
\text { deviation }\end{array}$ & $\begin{array}{l}\text { Variable } \\
\text { coefficient }\end{array}$ & Average & $\begin{array}{l}\text { Standard } \\
\text { deviation }\end{array}$ & $\begin{array}{l}\text { Variable } \\
\text { coefficient }\end{array}$ \\
\hline (1)Upstream rock-fill material & 41.9 & 2.17 & 0.05 & 2.76 & 1.18 & 0.43 \\
\hline (2)Downstream rock-fill material I & 51.24 & 3.22 & 0.06 & 7.73 & 1.88 & 0.24 \\
\hline (3)Downstream rock-fill material II & 49.4 & 1.5 & 0.03 & 7.9 & 1.3 & 0.16 \\
\hline (4) Reversed filter I & 43.82 & 2.08 & 0.05 & 4.62 & 1.94 & 0.42 \\
\hline (5) Reversed filter II & 47.17 & 2.48 & 0.05 & 6.9 & 1.6 & 0.23 \\
\hline (6) Transitional material & 46.68 & 2.48 & 0.05 & 5.8 & 1.6 & 0.28 \\
\hline (7) Gravel core wall material & 41.67 & 2.08 & 0.05 & 4.7 & 1.18 & 0.25 \\
\hline (8) Sand gravel of dam foundation & 49.03 & 2.45 & 0.05 & 7.42 & 1.86 & 0.25 \\
\hline
\end{tabular}

Table 4. Parameters of the stability calculation of Lianghekou dam

\begin{tabular}{|c|c|c|c|c|}
\hline \multirow[b]{2}{*}{ Dam materials } & \multicolumn{4}{|c|}{ Nonlinear strength } \\
\hline & $\mu_{\phi}$ & $\sigma_{\phi}$ & $\mu_{\Delta \phi}$ & $\sigma_{\Delta \phi}$ \\
\hline (1)Rock-fill material I & 49 & 2.02 & 6 & 1.136 \\
\hline (2)Rock-fill material II & 48 & 2.61 & 6 & 1.75 \\
\hline (3)Rock-fill material III & 43 & 1.73 & 6 & 1.01 \\
\hline (4) Reversed filter & 43.82 & 2.08 & 4.62 & 1.94 \\
\hline (5)Transition & 45 & 2.48 & 7 & 1.6 \\
\hline (6) Core wall & 41.67 & 2.08 & 4.7 & 1.18 \\
\hline
\end{tabular}

Design parameters of primary structures are presented in Table 1.

\section{DAM BODY DIVISION AND MATERIAL PA- RAMETERS OF EACH PROJECT}

In the design process of each project, a large number of studies and analyses are carried out on the division of the dam body. The influence of core wall structure on the dam slope stability is studied in this paper. As for the same project, the straight core wall and the slanting core wall are divided uniformly. Division schemes and material parameters are ultimately determined in each project.

In this paper, STAB program is adopted to calculate the safety factor of dam slope stability of the largest dam cross section of the clay embankment dam in each project. According to the current specifications and requirements, the safety factor of normal storage 
seepage line

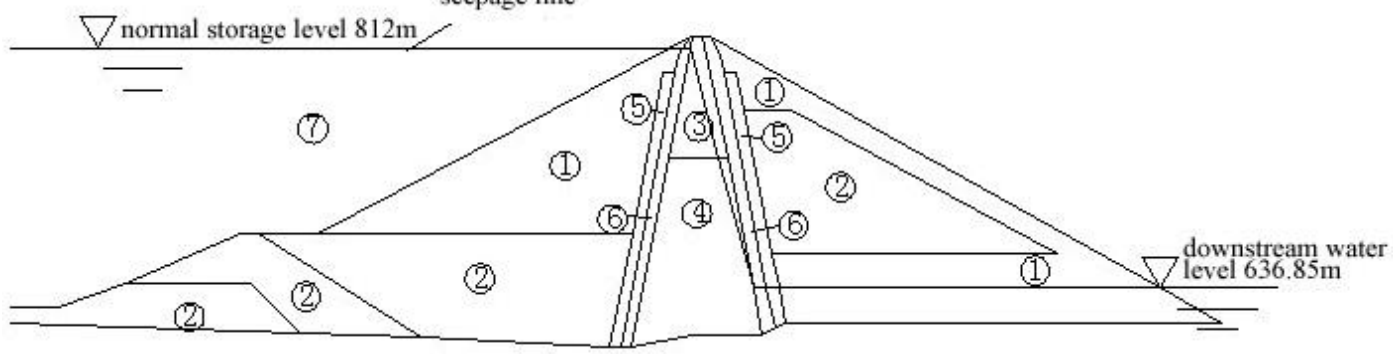

Figure 1. Analysis and calculation model of the stability of Nuozhadu dam

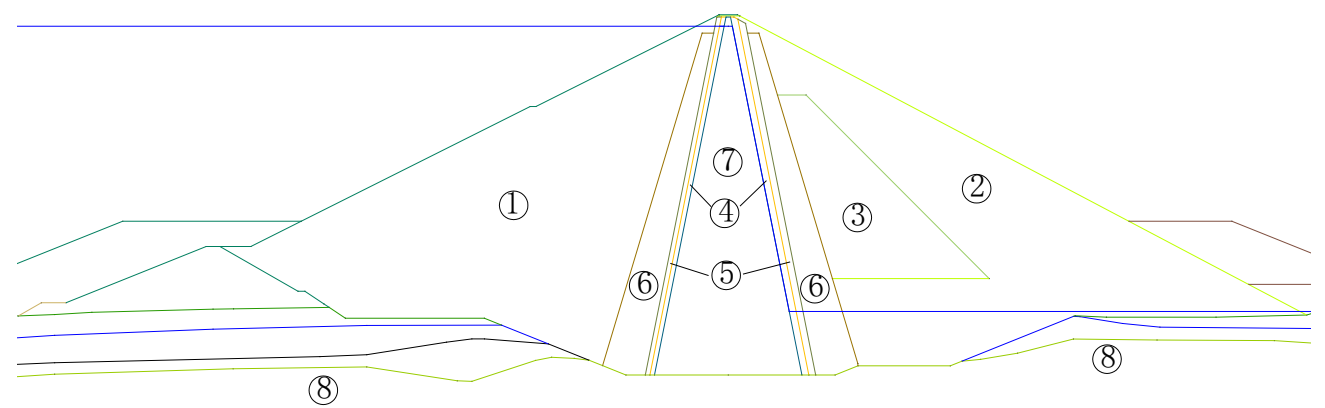

Figure 2. Analysis and calculation model of the stability of Shuangiiangkou dam

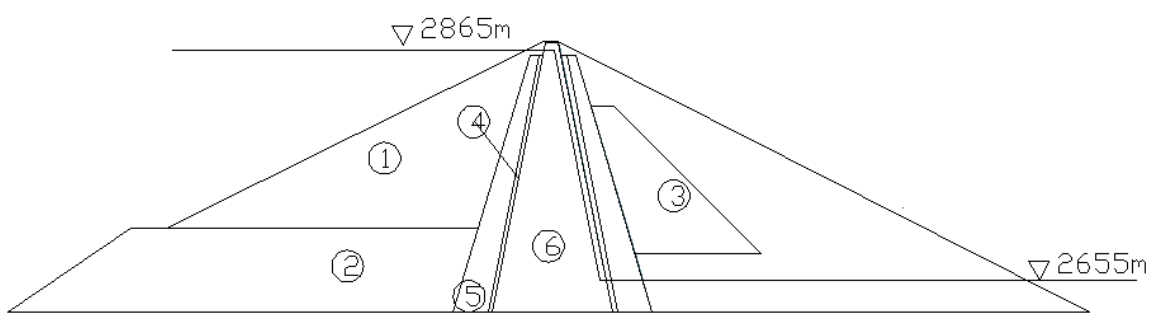

Figure 3. Analysis and calculation model of the stability of Lianghekou dam

period in each operating condition should be larger than 1.5 and that in the completion period and the sudden drawdown of the reservoir water level should be larger than 1.3. The safety factor in an earthquake should be larger than 1.2. Calculation models and numbers of all soil layers after the simplification are shown below:

1) Nuozhadu project

2) Shuangjiangkou project

3) Lianghekou project

4 ANALYTICAL COMPARISONS OF THE DAM SLOPE STABILITY OF DIFFERENT CORE WALL TYPES

The static stability and the quasi-static anti-seismic stability of dam slope are analyzed with the simplified
Bishop method based on the rigid limit equilibrium theory stipulated in the specification. Dam slope stability is calculated with "the slope stability calculation program of embankment dam STAB". It can be known from the calculation results that the minimum safety factor in each operating condition is larger than the permitted safety factor after weights which are added in the lower reaches. Therefore, it can be regarded that the dam body is stable and safe in all kinds of operating conditions. Safety factors of dam slope stability of all operating conditions are respectively calculated through the largest dam cross section. Safety factors of dam slope stability of straight and slanting core walls in different operating conditions are presented in the following table (take the minimum safety factor): 
EMME 2015

Table 5. Dam slope safety factors in different operating conditions

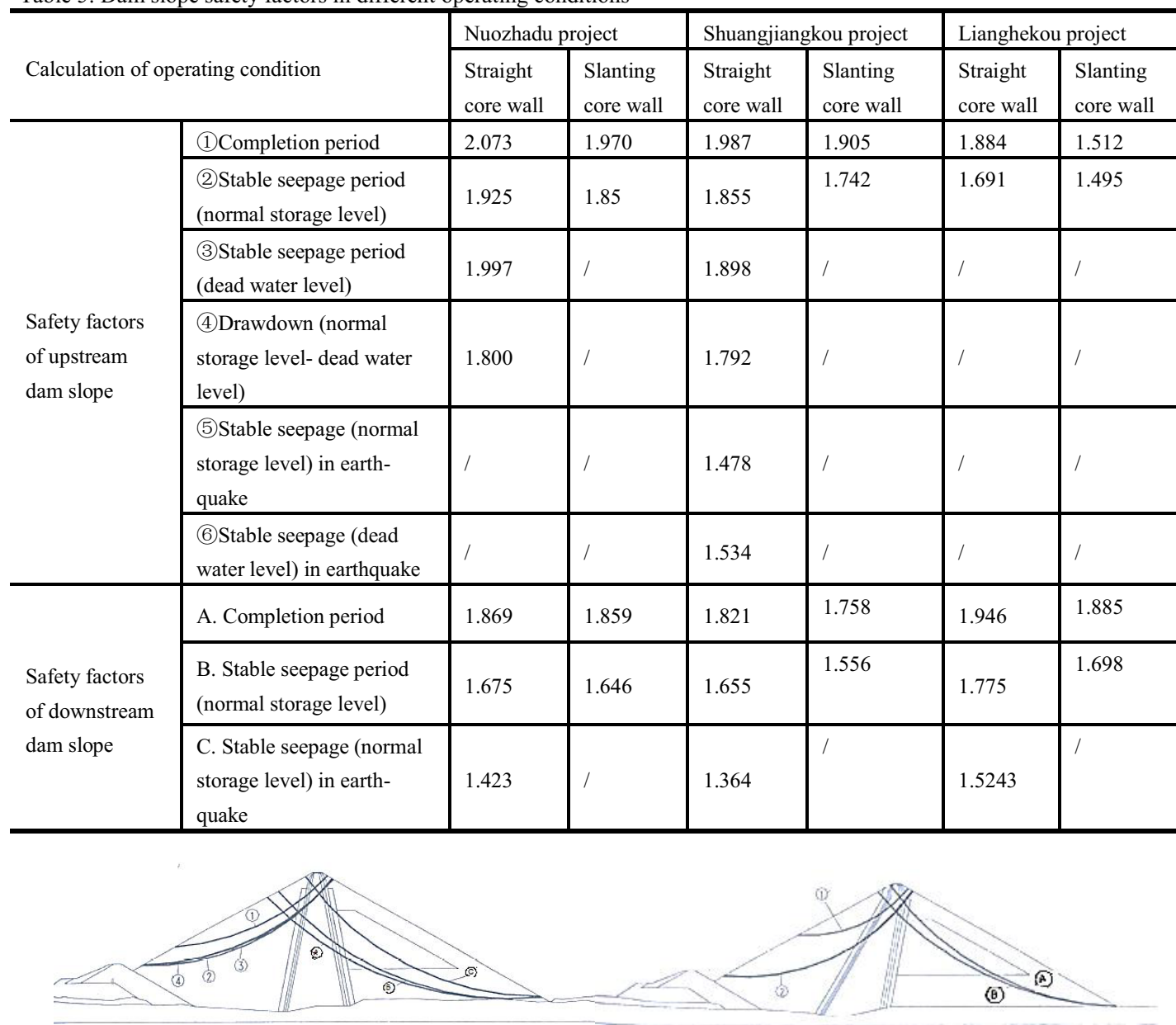

Figure 4. Schematic diagram of dangerous slip-crack surfaces in schemes of straight and slanting core walls in Nuozhadu

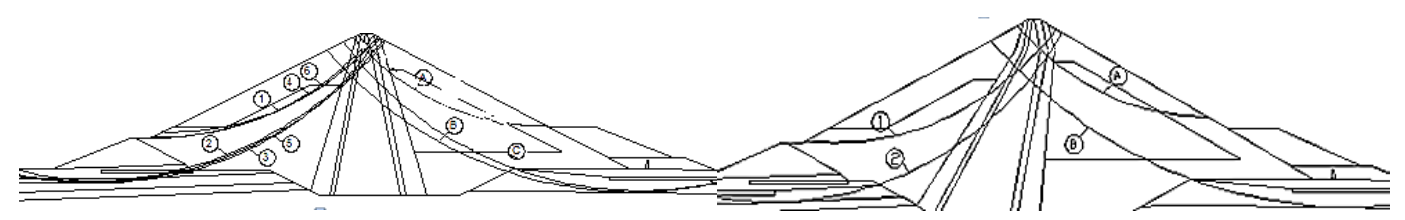

Figure 5. Schematic diagram of dangerous slip-crack surfaces in schemes of straight and slanting core walls in Shuangjiangkou

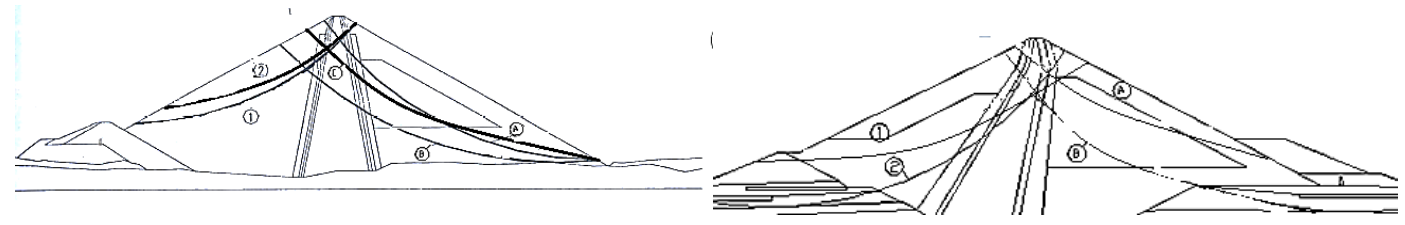

Figure 6. Schematic diagram of dangerous slip-crack surfaces in schemes of straight and slanting core walls in Lianghekou 


\section{MATEC Web of Conferences}

\subsection{Dam slope safety factors}

The above calculation results in table 5 show that the minimum safety factors of both the embankment dam with straight core wall and the embankment dam with slanting core wall are larger than the permitted safety factor. It means that the dam body is stable and safe. It can be seen from the comparison of the calculation results that the embankment dam with straight core wall has larger safety factor of the upstream dam slope especially in the condition of sudden drawdown of the reservoir water level. The discrepancy between the two in terms of safety factor of the downstream dam slope is small. The safety factor of the embankment dam with slanting core wall is relatively large. Therefore, from the aspect of the safety evaluation of dam slope stability, the safety margin of the embankment dam of straight core wall is larger than that of slanting core wall in the operating condition of the reservoir water level's drawdown. It means that the embankment dam of straight core wall is superior. The dam slope stability is not a decisive factor for the construction of high embankment dam. In the current design specification, the stipulation on anti-sliding stability of dam slope can be used to guide the design of high embankment dams of more than $200 \mathrm{~m}$.

\subsection{The most dangerous slip circle of dam slope}

Calculation results indicate that in the scheme of straight core wall, the safety factor in the stable seepage period after water storage is 1.675 when upstream and downstream water levels are normal. The destruction form is composite, including the initiative destruction of upstream rock-fill body and the downstream slope sliding. But the range of the upstream initiative destruction is larger and more obvious. The position of the most dangerous sliding part in the straight core wall scheme covers $2 / 3$ of the upstream dam slope while the position of the most dangerous sliding part in the slanting core wall scheme covers $1 / 3$ of the upstream dam slope. The position of the shear sliding surface in the lower reaches is relatively lower than that of the slanting core wall scheme. Compared with the straight core wall scheme, all positions of dangerous slip-crack surfaces of the downstream dam slope in the slanting core wall scheme are closer to the dam crest. The above-mentioned differences are caused by the large component of seepage force acted on the slanting core wall, which increases the downstream lateral stress of the core wall and enhances the shearing strength.

As for the slanting core wall scheme, the safety factor is 1.691 when the water level drops to the reservoir bottom. Most slip-crack surfaces appear on soft rock areas of the upstream slope. Both the upper and lower reaches have slip-crack surfaces, indicating that safety factors of upstream and downstream dam slopes are approximately equal. That is to say, the safety factor of the upstream dam slope is relatively reduced. It is the same as the case of the straight core wall that the upstream cofferdam and the lower rock-fill body are affected by the buoyancy force and the weight decreases. The safety factor of the upstream dam slope of the straight core wall embankment dam is larger especially when the reservoir water level suddenly falls. The difference between the two is quite small in terms of the safety factor of the downstream dam slope.

The safety factor of the straight core wall scheme with the most unfavorable water level of the upstream dam slope in the stable seepage period is 1.997 while the safety factor of the slanting core wall scheme is 1.844. If the operating condition is in an earthquake, the most unfavorable sliding surface is still a circular slip-crack surface. The reinforcement of the dam crest position is a key factor for the slope stability when the embankment dam slope is strengthened or designed.

\section{CONCLUSION}

Although the selection of core wall type should be based on comprehensive considerations of such objective factors as geography, geological conditions, junction layout, construction and cost, this paper only carries out a study on structural forms of core wall from the angle of dam slope stability. Stability factors like dam slope stability, dam body stress and strain and seepage of dam body and dam foundation should also be taken into account

(1) The current embankment dam design specification can be used as the guidance for the design of embankment dam slope stability of more than $200 \mathrm{~m}$. The safety factor in the normal storage period is larger than 1.5; the safety factor in the completion period and in the sudden drawdown of the reservoir water level is larger than 1.3; the safety factor in earthquake is larger than 1.2. The Nuozhadu embankment dam conforms to the design specification of embankment dams and the dam slope stability is not a decisive factor for the construction of high embankment dam.

(2) Compared with the straight core wall scheme, all positions of dangerous slip-crack surfaces of the downstream dam slope in the slanting core wall scheme are closer to the dam crest. It is caused by the large component of seepage force acted on the slanting core wall, which increases the downstream lateral stress of the core wall and enhances the shearing strength. The dangerous slip-crack surface with the most unfavorable water level of the upstream dam slope in the stable seepage period and the dangerous slip-crack surface of dam slope in an earthquake have the same position. And the reinforcement of the dam crest position is a key factor for the slope stability when the embankment dam slope is strengthened or designed. 


\section{REFERENCES}

[1] Zhang, Z.L. 2005. A study on features and key technologies of Nuozhadu Hydropower Station project, Journal of Hydroelectric Engineering, 31(5): 4-7.

[2] Zhang, Z.L., Yuan, Y.R. \& Feng, Y.L. 2007. A study on key technologies of high embankment dam with a core wall in Nuozhadu Hydropower Station, Journal of Hydroelectric Engineering, 32(11): 5-8.

[3] Xu, Q., He, J.D. \& Xie, H.Q., et al. 2014. A study on underground seepage fields and seepage control measures of the high embankment dam of $300 \mathrm{~m}$, Water Resources and Power, (7).

[4] Guo, D.Q., Yan, J. \& Yang, X.G., et al. 2014. The three-dimensional nonlinear finite element analysis of the high embankment dam in Pubugou, Yellow River, (5).

[5] Yang, J. 2015. Defect analysis on embankment dams, China New Technologies and Products, (5): 52-61.
[6] Chen, Z.Y. 2003. Soil Slope Stability Analysis_-Theory, Methods and Programs. Beijing, China Water Power Press.

[7] Li, G.Y., Wang, L.S. \& Mi, Z.K. 2004. A study on the stress and strain of embankment dam with a clay core wall, Chinese Journal of Rock Mechanics and Engineering, 23(8): 1363-1369.

[8] Lian, Z.Y., Han, G.C. \& Kong, X.J. 2001. A study on the stability of excavation slope with strength reduction FEM, Chinese Journal of Geotechnical Engineering, 23(4): 407-411.

[9] Chen, S.S. 2015. Research and application of new technologies of embankment dam, Chinese Journal of Geotechnical Engineering, 37(1):1-28.

[10]Chen, S.S., Fang, X.S. \& Zhong, Q.M., et al. 2014. Centrifugal model test and numerical simulation of the overtopping and dam-break process of embankment dam (English), Chinese Journal of Geotechnical Engineering, (5).57-66.

[11]Jiang, S.L. \& Qiu, X.L. 2015. A comparative study on test methods of permeability coefficient of anti-seepage core wall materials for embankment dam, Yangtze River, (8): $34-45$ 